\title{
The Impact of Hydropeaking on Juvenile Brown Trout (Salmo trutta) in a Norwegian Regulated River
}

\author{
Svein Jakob Saltveit ${ }^{1, *}$, Åge Brabrand ${ }^{1}$, Ana Juárez ${ }^{2}{ }^{\mathbb{D}}$, Morten Stickler ${ }^{3,4}$ and \\ Bjørn Otto Dønnum ${ }^{5}$ \\ 1 Freshwater Ecology and Inland Fisheries Laboratory, Natural History Museum, University of Oslo, \\ P.O. Box 1172, Blindern, 0318 Oslo, Norway; age.brabrand@nhm.uio.no \\ 2 Department of Civil and Environmental Engineering, Norwegian University of Science and Technology, \\ 7031 Trondheim, Norway; ana.juarez@ntnu.no \\ 3 The Norwegian Water Resources and Energy Directorate, 0301 Oslo, Norway; mst@nve.no \\ 4 Department of Natural Sciences and Environmental Health, University of Southeast Norway, \\ 3800 Bø, Norway \\ 5 Hafslund E-CO Vannkraft AS, 0104 Oslo, Norway; bjornotto.donnum@hafslundeco.no \\ * Correspondence: s.j.saltveit@nhm.uio.no
}

Received: 31 August 2020; Accepted: 13 October 2020; Published: 19 October 2020

\begin{abstract}
The Norwegian electrical energy supply system is based on hydropower. The now deregulated energy market has led to increased use of hydropeaking production, leading to greater fluctuations in discharge and water levels below hydropower stations. The power station HOL 1, with an outlet to the Storåne River, is a large hydropeaking facility. With over 300 rapid flow increases and decreases per year since 2012, it is a river subjected to frequent hydropeaking. To quantify the stranding risk downstream of the power plant, the effect of a series of different turbine shutdown scenarios was simulated in an earlier study. The residual flow of $6 \mathrm{~m}^{3} \cdot \mathrm{s}^{-1}$ and a full production of $66 \mathrm{~m}^{3} \cdot \mathrm{s}^{-1}$ were considered as the baselines for the calculation of dewatered areas. A three-year study of juvenile fish density both upstream as a reference and downstream of the power plant was undertaken. There were very low densities or even an absence of brown trout (Salmo trutta) older than young-of-the-year (YoY) below the outlet of the power station, despite high densities of YoY in previous years. This is probably due to the large and rapid changes in flow below the power station. Hydropeaking has less impact on the earliest life stages of brown trout during spring and summer, as well as on spawning and egg development during winter. This is attributed spawning in late autumn occurring at a low flow seldom reached during hydropeaking. The high survival of YoY during the first summer and early autumn is likely due to a lower frequency of hydropeaking and higher residual flows, leaving a larger wetted area.
\end{abstract}

Keywords: river regulation; hydropeaking; brown trout; fish density

\section{Introduction}

Climate change, as a driving factor for the future European energy market, favors for the use of renewable energy, with the contribution of solar and wind energy and using hydropower as a base load increasing [1]. The Norwegian electrical energy supply system is nearly $100 \%$ based on hydropower [2]. The now deregulated energy market has led to increased use of hydropeaking, causing rapid changes in downstream flow. Differences in energy prices between day and night, an increase in the import and export of electrical energy, and intermittent electricity generation from solar and wind energy delivering balancing power are the main reasons for changes in power production patterns. This has led to increased hydropeaking production, leading to higher fluctuations in discharge and water levels below 
hydropower stations. Future hydropower production can therefore be expected to be characterized by short-term peak production dependent on energy prices, marked demand, and profitability from wind and solar energy [2].

The power station HOL 1 with outlet to the Storåne River in the Hallingdal watercourse is a large hydropower station that delivers power on request from the Norwegian national grid. In Norway, there has been an increase in requests for balancing power since 2010, with increased use of hydropeaking. Over 300 rapid flow increases and decreases per year since 2012 indicate a river subjected to frequent hydropeaking [3]. To quantify the stranding risk downstream of the power plant, Juárez et al. [3] simulated the effect from a series of different turbine shutdown scenarios. A residual flow set at $6 \mathrm{~m}^{3} \cdot \mathrm{s}^{-1}$ and full production set at $66 \mathrm{~m}^{3} \cdot \mathrm{s}^{-1}$ were considered as the baselines for the calculation of dewatered areas.

The power station has four Francis turbines, each one with a capacity of $15 \mathrm{~m}^{3} \cdot \mathrm{s}^{-1}$. A typical downstream dewatering or riverbed drainage event is a discharge decrease of $15 \mathrm{~m}^{3} \cdot \mathrm{s}^{-1}$ in $5 \mathrm{~min}$ for each turbine. Alternative scenarios involved discharge decreases from full production to zero in $30 \mathrm{~min}$. Several simulation results were obtained by decreasing from all four turbines down to only one [3]. The dewatered areas were calculated as a function of the number of turbines that were running at the start and at the end of each scenario, from a reference discharge of $66 \mathrm{~m}^{3} \cdot \mathrm{s}^{-1}$, representing full production and no dewatered area, to zero turbines running, representing residual flow and 35\% dry area. Even if most of the rapid increases started and the decreases stopped at relatively high discharges especially during winter, $25 \%$ of the fluctuation limits were $<16 \mathrm{~m}^{3} \cdot \mathrm{s}^{-1}$ and $10 \%$ were $<8 \mathrm{~m}^{3} \cdot \mathrm{s}^{-1}$. Furthermore, the ramping down rate downstream from the power station outlet was considered when calculating the dewatering speed. According to Halleraker et al. [4], ramping down rates should be $<10 \mathrm{~cm} \cdot \mathrm{h}^{-1}$ to limit the stranding fish risk.

The main environmental impact of hydropeaking on fish is stranding, causing mortality [5]. In several Norwegian regulated rivers, like the Nidelva, Suldalslågen, Surna, and Alta, stranding and mortality of fish are connected to sudden and strong reductions in flow [6-9]. Fish may strand on flat riverbanks or be trapped in pools disconnected from the main channel $[4,5,10,11]$. Young-of-the-year (YoY) Atlantic salmon (Salmo salar) and brown trout (Salmo trutta) seem to be more severely affected than older juveniles, as areas inhabited by YoY are more exposed than habitats used by older fish [12,13]. However, stranding is not always equivalent to mortality, as fish can survive for several hours after dewatering [11]. Hydropeaking-induced stranding mortality may affect the Atlantic salmon population across multiple generations [14]; this is also likely for brown trout.

Hydropeaking may also reduce the quality of fish habitat and change fish community structures by changes in current speed [15,16] and by the stranding of invertebrates [17]. Benthic macroinvertebrates are potentially vulnerable in shallow riffle habitats [18,19]. Invertebrate abundance in rivers affected by hydropeaking demonstrates a lateral gradient from the most exposed areas having a low overall abundance through to the permanently wetted zone, which has invertebrate abundance and diversity similar to natural systems or unaffected reaches $[20,21]$. The prevailing opinion is that repeated drift or involuntarily downstream migration induced by hydropeaking depletes the benthic macroinvertebrate community [22]. Consequently, both invertebrate drift and benthic-feeding fish species are affected by the potentially limited supply of their major food source in these habitats. Studies have also revealed the negative impacts on aquatic ecosystems in general and ecosystem services such as kayaking and recreational fishing [23].

The study by Juárez et al. [3] did not include brown trout densities in the Storåne River. The aim of our study was therefore to achieve a better understanding of the population effects of hydropeaking on brown trout. The results will provide a basis for future mitigation strategies to reduce juvenile fish stranding. The study design is based on quantitative comparisons of juvenile fish density upstream (reference) and downstream of an existing hydropower plant. 


\section{Material and Methods}

\subsection{Study Site}

The study site, the Storåne River, runs from Lake Strandavatnet through Lake Sudndalsfjord and Lake Hovsfjorden to Lake Holsfjorden, all located in the Hol municipality in central southern Norway (Figure 1). The studied river reach, containing the outlet of the HOL 1 power plant, is an approximately $3 \mathrm{~km}$ river section above Lake Hovsfjord. The reach downstream of the power station affected by hydropeaking is $2.0 \mathrm{~km}$. The first $400 \mathrm{~m}$ downstream of the outlet is an artificially laid stone trapezoidal channel, whereas the rest of the river is a natural braided river section with several side channels forming three main islands. The Storåne River has clear water and is relatively shallow (mean depth $<1 \mathrm{~m}$ ). The mesohabitat varies between glide and riffle, with some steep sections. The total river length accessible for trout migrating upstream from Lake Hovsfjorden is $8.1 \mathrm{~km}$.

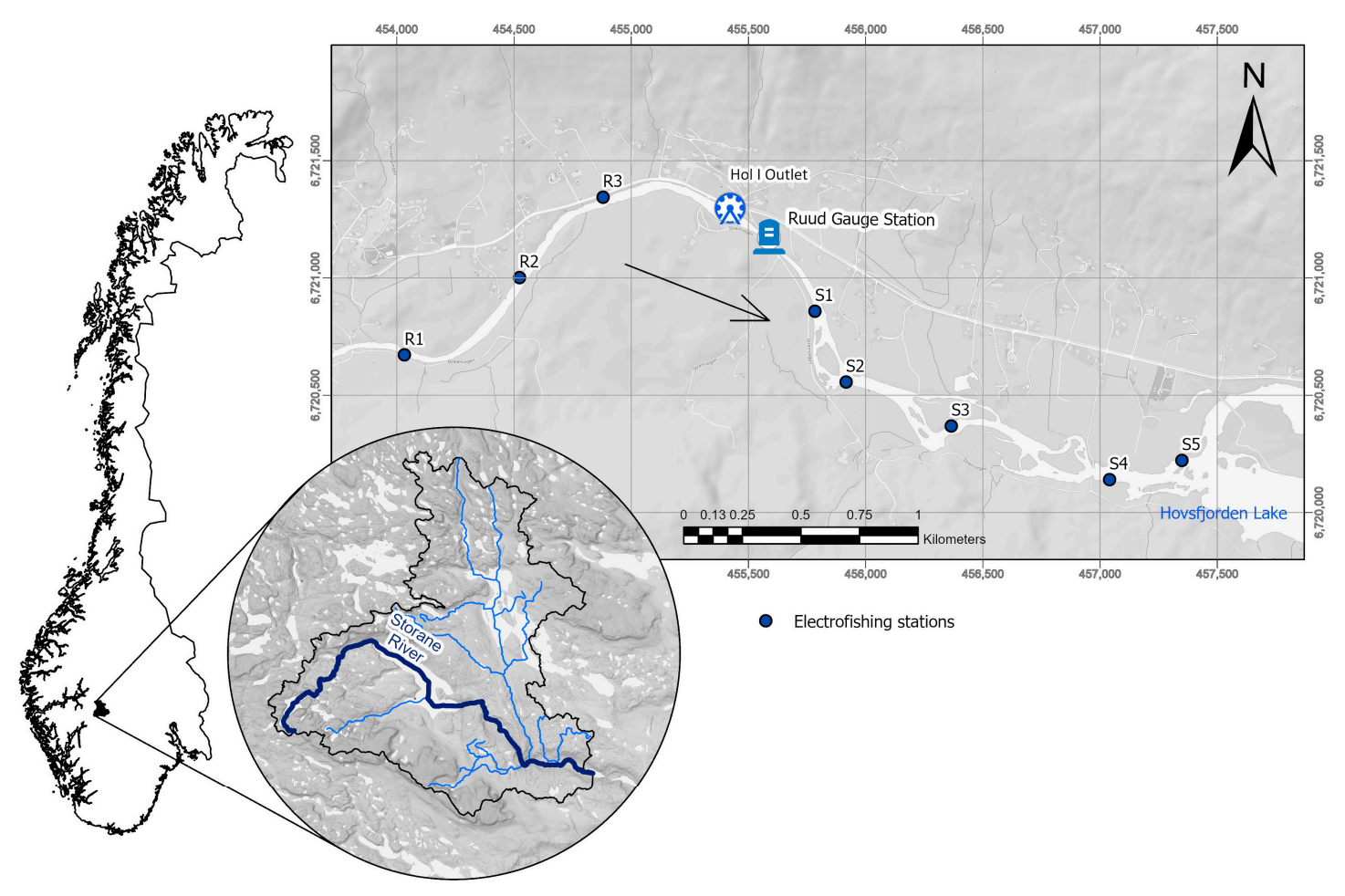

Figure 1. The Storåne River in Norway with the locations for sampling fish. R1-R3, river sections upstream from the power station (HOL 1); S1-S5, hydropeaking sections downstream from HOL 1. The arrow shows the direction of river flow.

The HOL 1 hydro power station, built in the period 1940-1956, has four high-head Francis turbines in two groups; receiving water through two pipelines from two different high mountain reservoirs Urunda (head $=399 \mathrm{~m}$ ) and Votna (head $=407 \mathrm{~m}$ ). The capacity was upgraded in the period 2009-2012 for delivering grid stabilizing services, both for regulating voltage and frequency in the national grid. There is no dam on the River Storåne.

\subsection{Methods}

Electrofishing was carried out at eight stations along the Storåne River (Figure 1) in the autumns of 2016, 2017, and 2018. Three stations (R1-R3) were located above the outlet of the Hovet power station (HOL 1) and were regarded as a reference for five stations (S1-S5) below the outlet of the power station, which were influenced by the operation of the power station. 
The localities had habitat (substrate and current) suitable for both YoY and older trout. However, one locality upstream had a substrate more suitable for older trout (R3), whereas one downstream site was more suitable for YoY (S5).

Fish density at the eight stations was calculated via successive removal, using three subsequent catches [24-26], with a 20 min break between each removal. We used an electric fishing device designed by Terik Technology. Its maximum voltage is $1600 \mathrm{~V}$ and the pulse frequency is $80 \mathrm{~Hz}$. Density, given as number of fish per $100 \mathrm{~m}^{2}$, was estimated for all stations. In the calculations of trout density, YoY and older juveniles ( $\geq 1$ one year) were separated by size. YoY were, in general, between 40 and $60 \mathrm{~mm}$, whereas older juveniles were larger than $70 \mathrm{~mm}$.

\subsection{Hydrological Analysis}

The time series of hourly discharge from 2016 to 2018 in the reach below the power station was provided from the Ruud gauging station, located $100 \mathrm{~m}$ downstream of the power station outlet (Figure 1). It measures the flow through the HOL 1 power station plus the flow from the Storane River above the power station. The flow from the Storåne River upstream from the power station was calculated from the difference between the flow at Ruud and the production flow from the HOL 1 power station.

\subsection{Statistical Analysis}

Potential differences in the continuous response variable fish density across factors (years or stations) were tested with one-way ANOVA [27].

\section{Results}

\subsection{River Flow}

The flow on the impacted downstream reach is characterized by large and frequent hydropeaking events (Figure 2) and is mainly determined by the production flow from the HOL 1 power station. The demand for energy is high in late autumn and winter. Running on maximum load, the flow is therefore usually higher from about 1 October until 1 May (winter) than during summer, 1 May until 1 October. Thus the peaks are also larger and more frequent during winter (Figure 2). The residual flow from the bypassed river section upstream of the outlet from the power station is generally low but is higher in summer than in winter (Figure 2).

The river flow lowering speed is $7 \%$ slower in summer than in winter: $5.25 \mathrm{~m}^{3} \cdot \mathrm{s}^{-1} \cdot \mathrm{h}^{-1}$ in summer and $4.9 \mathrm{~m}^{3} \cdot \mathrm{s}^{-1} \cdot \mathrm{h}^{-1}$ in winter. The frequency of hydropeaking is very high and twice as many hydropeaking events occur during winter than during summer (Table 1). During the period from 2010 to 2020, a mean of 57 decreasing peaks occurred per month; of these, 42 (74\%) occurred at night. In summer, an average of 33 decreasing peaks per month (75\%) occurred at night (Table 1$)$.

Flow duration curves from the bypass section above the power station from 2010 to 2019, for both summer and winter, show that the flow from the bypass section above the power station is higher in summer than in winter (Figure 3). When the flows were below $12 \mathrm{~m}^{3} \cdot \mathrm{s}^{-1}$, the dewatered area increased much faster, and flow below $6 \mathrm{~m}^{3} \cdot \mathrm{s}^{-1}$ led to a large increase in dry areas when the power station was shut down completely [3]. However, due to higher flow from the bypass section during summer, flows above $6 \mathrm{~m}^{3} \cdot \mathrm{s}^{-1}$ only occurred $35 \%$ of the time; $70 \%$ of the time, flows were lower than $12 \mathrm{~m}^{3} \cdot \mathrm{s}^{-1}$ downstream from the power station. During winter, residual flows below 6 and $12 \mathrm{~m}^{3} \cdot \mathrm{s}^{-1}$ occurred as often as $75 \%$ and $93 \%$ of the time, respectively. This means that when there is a complete turbine shutdown, the possibility that the final flow will be critical for fish stranding is far greater in winter than in summer. However, most of the rapid decreases stopped at relatively high discharge (median $\left.34.61 \mathrm{~m}^{3} \cdot \mathrm{s}^{-1}\right)[3]$. 

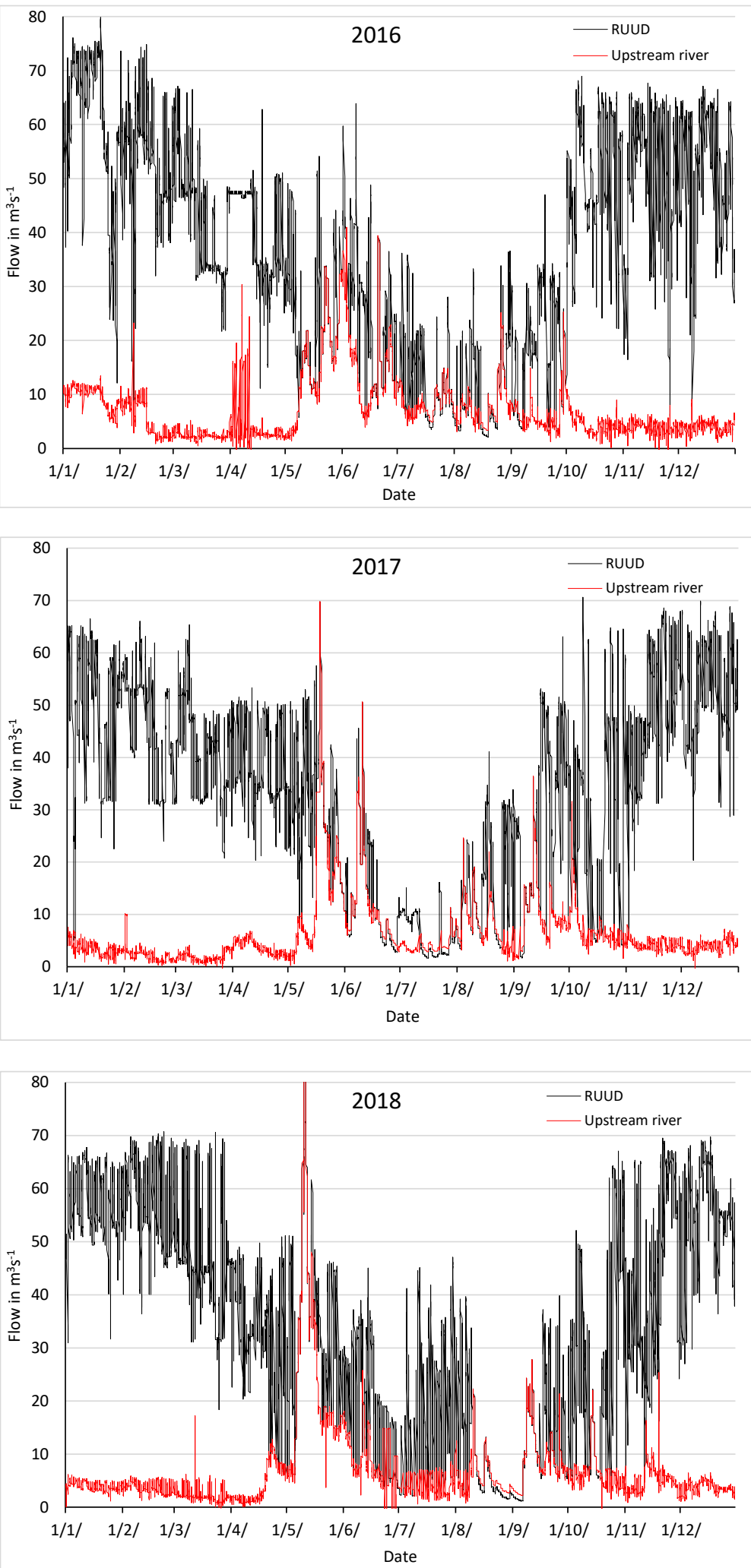

Figure 2. Hourly flow in the Storåne River at the Ruud gauging station (black) on the impacted reach downstream from the power station HOL 1 and in the river section upstream from the power station (red) in 2016, 2017, and 2018. 
Table 1. Number of decreasing peaks (mean) per month during summer and winter in daylight and darkness during the period from 2010 to 2019 in the Storåne River.

\begin{tabular}{ccc}
\hline & \multicolumn{2}{c}{ Decreasing Peaks/Month } \\
\hline Time & Summer & Winter \\
Daylight & 8 & 15 \\
Darkness & 25 & 42 \\
Total & 33 & 57 \\
\hline
\end{tabular}

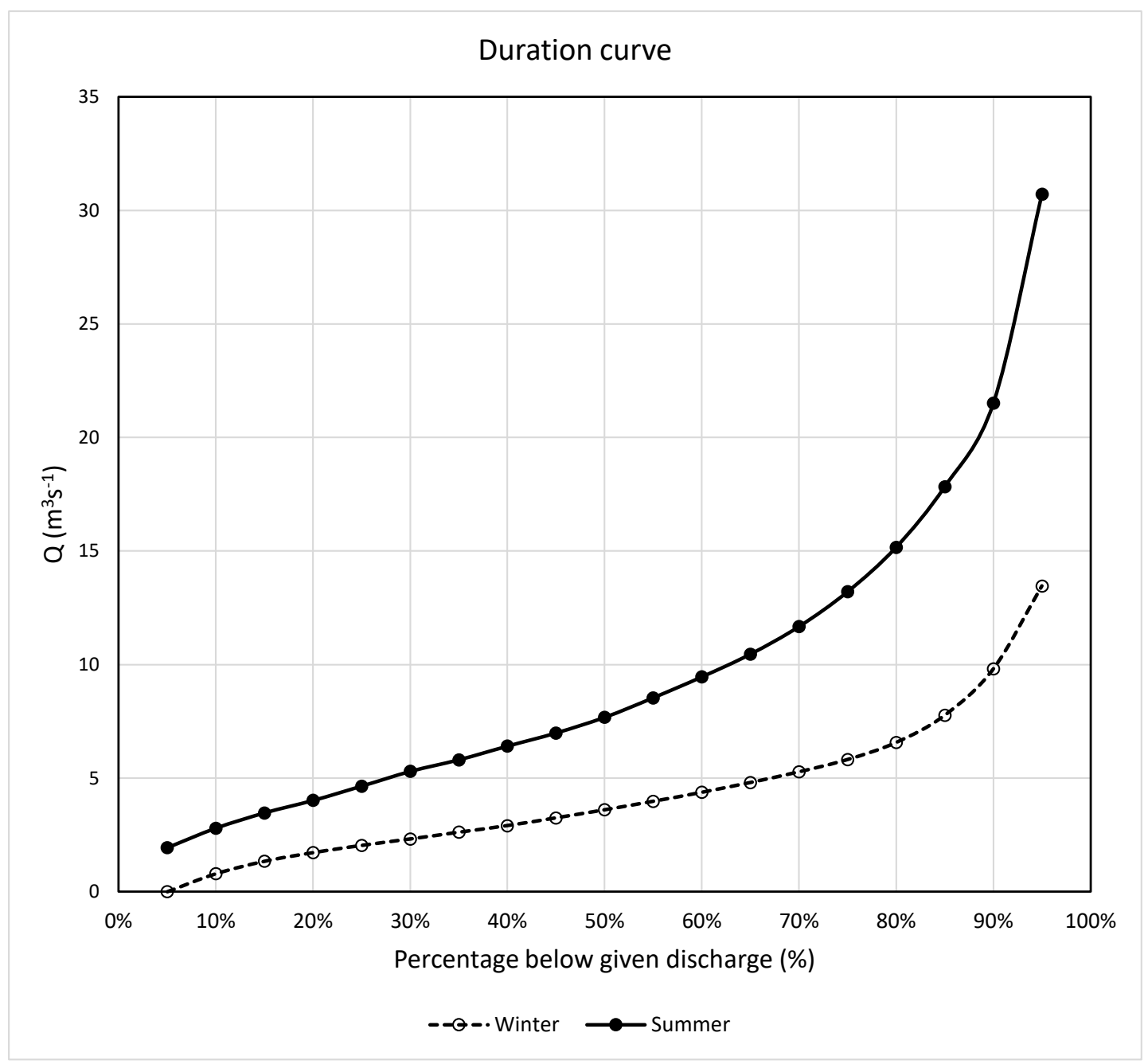

Figure 3. Flow duration curves for both summer and winter for flow on the impacted section below the HOL 1 power station, based on hourly discharge measurements. Summer: 1 May to 1 October; winter: 1 October to 1 May.

\subsection{Fish Density}

Below the power station, no brown trout were present in catches at station S1 in all three years and none at station S3 in 2016, though they were present in every year at all other stations below the outlet (Figure 4). At the three reference stations above the station, YoY and older juveniles were caught in each year (Figure 4). The only exception was 2018, when no YoY were present in the catch at station R3. 

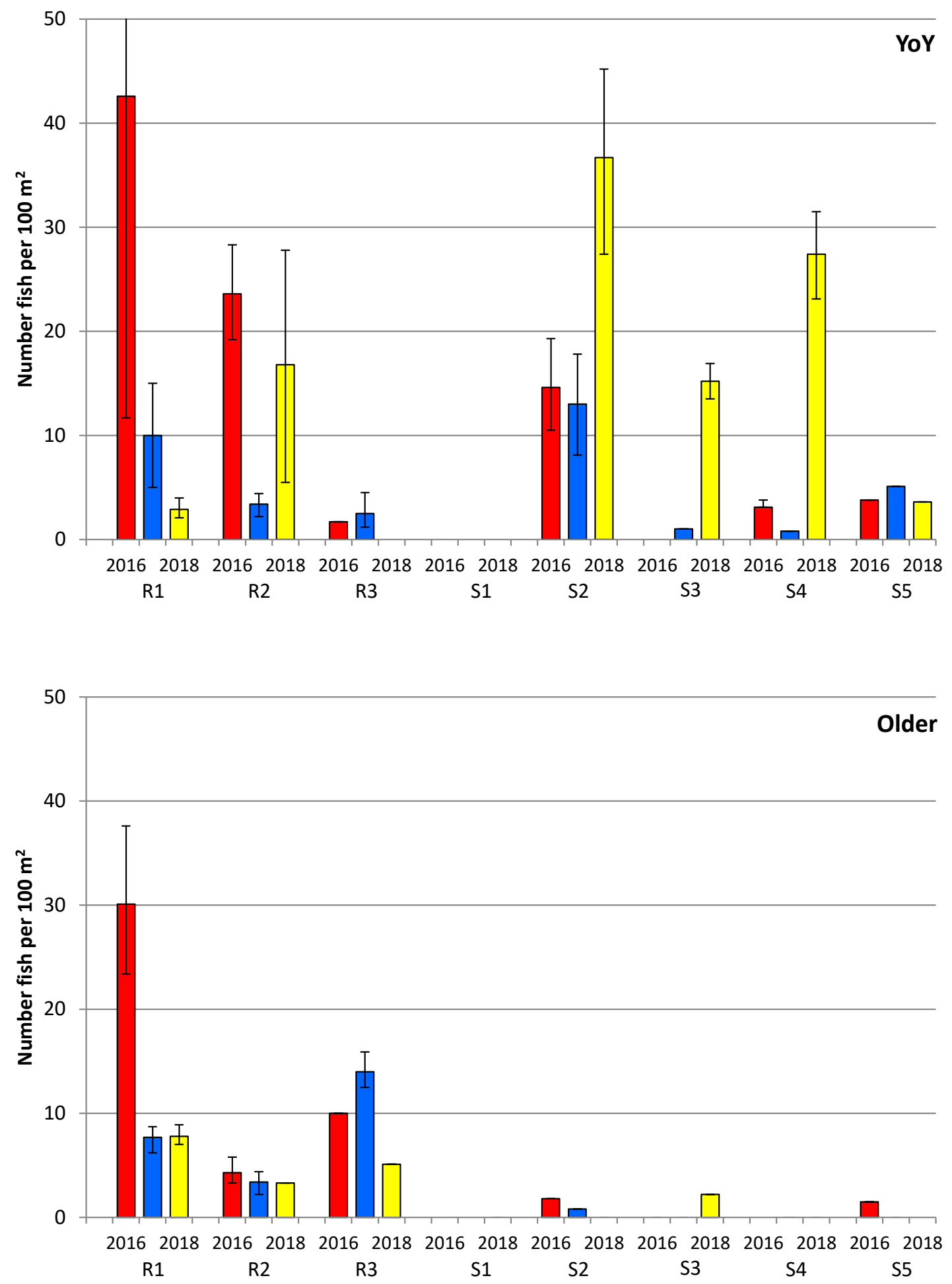

Figure 4. Density (number of fish per $\mathrm{m}^{2}$ ) with $\pm 95 \% \mathrm{CI}$ at different localities in the Storåne River in 2016, 2017, and 2018. Stations R1-R3 are on the bypass reach above the HOL 1 power station and stations S1-S5 are below the power station.

In 2016, the density of trout, both YoY and older, was significantly higher at the reference stations than at the stations below HOL 1 (S1-S5). The density of YoY trout was then particularly high at the two uppermost stations but low at R3 due to unsuitable substrate, large stones, and blocks. In 2017 
and 2018, R1 and R2 had significantly lower YoY densities, whereas only R1 had lower older juvenile densities in 2017 and 2018 compared with 2016. There is no apparent correlation between YoY density and older trout the following year (one-way ANOVA).

The density of YoY at some of the stations downstream of the power station was relatively high (Figure 4), particularly at station S2 in all three years and S3 and S4 in 2018. At station S5, the YoY density was stable but low due to an unstable substrate of small stones, coarse gravel and sand. Despite high YoY densities, older trout $\geq 1$ year old, when present, were found only in very low densities at the stations below the power station (Figure 4).

In summary, one-way ANOVA showed no statistical difference in the density of YoY or older trout across years (YoY/years: $p=0.362, \mathrm{~F}=1.065$; older trout/years: $p=0.55, \mathrm{~F}=0.615$ ). There was no significant difference in fish density across stations for YOY (one-way ANOVA, $p=0.231 ; \mathrm{F}=1.516$ ). However, for trout older than YoY, a clear statistically significant difference was found across stations $(p=0.0101 ; \mathrm{F}=4.019)$ due to the large difference in density above and below the power station.

\section{Discussion}

The main impact of the hydropeaking operations in the Storåne River was the very low density or absence of brown trout older than YoY below the outlet of the power station, despite high densities of YoY in the previous years. This may be due to several reasons but is probably attributed to the large and rapid changes in flow below the power station caused by hydropeaking operations (Juárez et al. 2019). The analysis by Juárez et al. [3] of the flow time series in the Storåne River showed that in the period 2012-2017, there were, on average, over 280 rapid decreases during the year, typical of the pattern in a highly impacted hydropeaking river [28].

Hydropeaking had less impact on the earliest life stage of brown trout, YoY, during spring and summer. The estimated density of YoY was high in the autumn in the reach below the power station and was even higher than the density at the reference stations.

The main effect of hydropeaking on juvenile salmonids in rivers is mortality due to stranding and desiccation $[11,14,29]$. However, hydropeaking can also lead to increased mortality due to increased energy consumption and stress [30]. The lower density of juveniles aged $\geq 1$ year in the Storåne River might be due to involuntary juvenile drift or downstream migration into the lake below [31], especially during autumn and winter, when the size, frequency, and speed of the hydropeaking increase. In addition, periodic and frequent fluctuations of gas supersaturation, called saturopeaking and which follow the pattern of hydropeaking events, cannot be excluded as a factor [32], especially in the upper part of the river close to the power station outlet where no trout were found.

The high density of YoY in autumn indicates that not only were the juvenile fish less affected during summer but so were spawning during late autumn and egg development during winter below the power station. Hydropeaking can potentially lead to dewatering of salmonid spawning redds and then to mortality of early life stages, such as eggs and alevins [28], with higher impact on the alevins due to lower tolerance to dewatering than the eggs [33]. Even though the hydropeaking operations are more severe during late autumn and winter, both larger and more rapid; this does not seem to influence the gravel stages of trout and then the recruitment of YoY. This is attributed to spawning in the autumn occurring at a flow seldom reached during hydropeaking in winter and early spring and only during short total shutdowns. According to Juárez et al. [3], most of the rapid decreases during drift stopped at relatively high discharges during winter (mean $29.72 \mathrm{~m}^{3} \cdot \mathrm{s}^{-1}$ ) (see Figure 2), dewatering only $\sim 15 \%$ of the downstream river bed [3].

Spawning below a discharge of $\sim 30 \mathrm{~m}^{3} \cdot \mathrm{s}^{-1}$ means that redds are rarely left dry during hydropeaking operations during winter, leaving the redds wet most of the time during winter. Thus redds are only dewatered occasionally for shorter periods during a total shutdown of the power station or when only running on the lowest load. Eggs tolerate shorter periods of dewatering as long as they are moist and not frozen [34]. The influx of groundwater to the redds may also play an important role in the survival of salmonid eggs [28], although no information on the influx of groundwater is available 
for the Storåne River. Even if $25 \%$ of the flows are below $16 \mathrm{~m}^{3} \cdot \mathrm{s}^{-1}$ and $10 \%$ are lower than $8 \mathrm{~m}^{3} \cdot \mathrm{s}^{-1}$, most occur after hatching and swim-up and when the flow from the upstream section is high (Figure 2).

The high survival of YoY during the first summer and early autumn is due to the lower frequency of hydropeaking and the higher residual flow from the bypass section, which has a dampening effect on the peaks and leaves a larger area not dewatered during the rapid decreases or when the power station is not running.

Temperature, season, and light conditions have the most pronounced effect on the stranding of juvenile salmonids. In general, a far higher incidence of fish stranding occurs during winter conditions $\left(<4.5^{\circ} \mathrm{C}\right)$ compared with during summer and early autumn [11]. This is mainly because of lower fish activity during the cold season and substrate-seeking behavior, especially during daytime. Stranding is lower at night during winter [11], probably because of the predominant night active behavior of juvenile brown trout [35]. In the Storåne River, $70 \%$ of the decreases occur during the night [3], which might reduce stranding incidents during winter. Long, slow shutdown procedures of the turbines during daytime with water level changes of $<20 \mathrm{~cm} \cdot \mathrm{h}^{-1}$ decreased the stranding of Atlantic salmon drastically [11]. It may therefore be possible to reduce stranding by taking such ecological considerations into account during hydropeaking operations.

Seasonal analysis showed that the highest percentage of rapid decreases occurs during darkness in winter and autumn [3]. According to refs. [11,14,36,37], there is a far higher risk of fish stranding during daylight in winter conditions due to the activity patterns of the fish [35]. Therefore, restricting dewatering to the night may reduce the risk of stranding.

Juárez et al. [3] outlined the principal methods that can be used to reduce hydropower's impact, such as operational measures or building dikes or pools to decrease the effect of hydropeaking flows downstream, although all have operational and construction costs. From the point of view of fish biology, changes in the operation of the power station are the optimal strategy. Other mitigation strategies suggested by ref. [3] involving morphological changes would probably worsen fish habitats.

Mitigation measures should target juvenile brown trout $\geq 1$ year old during winter. Stranded fish have occasionally been observed (M. Stickler, pers. comm.). However, stranding does not seem to be the main impact. Dewatered areas mostly appear below $12 \mathrm{~m}^{3} \cdot \mathrm{s}^{-1}$, reaching $34 \%$ at $6 \mathrm{~m}^{3} \cdot \mathrm{s}^{-1}$. According to the Envipeak guidelines [38], dewatered areas greater than $20 \%$ are considered to have a major impact. During winter, most of the rapid decreases stop at relatively high discharges (mean $29.72 \mathrm{~m}^{3} \cdot \mathrm{s}^{-1}$ ), inundating only small areas [3]. The simulation results showed that with the current operational procedures, the main impact during winter is a dewatering rate of $>20 \mathrm{~cm} \cdot \mathrm{h}^{-1}$ [3]. In addition, there is a high frequency of such large decreases and increases in flow. Changes in water discharge and water level of this magnitude have been shown to affect behavior in Atlantic salmon and brown trout, which can lead to higher mortality during winter $[4,39,40]$. Although we have no data to support this, we think that the lack of $\geq 1$ year old trout below the power station may be due to drift or migration into the lake below. The high densities of YoY indicate extensive spawning in the reach below the power station and is likely to be an important recruitment area for trout to Lake Hovsfjord.

Author Contributions: Conceptualization, S.J.S. and Å.B.; Methodology, S.J.S. and Å.B.; Software, A.J.; Investigation, S.J.S. and Å.B.; Resources, B.O.D.; Data Curation, S.J.S.; Å.B. and A.J.; Writing一Original Draft Preparation, S.J.S.; Writing—-Review \& Editing, S.J.S.; Å.B. and M.S.; Funding Acquisition, B.O.D. All authors have read and agreed to the published version of the manuscript.

Funding: This research was funded by Hafslund E-CO Vannkraft AS.

Acknowledgments: Thanks are due to John E. Brittain for comments and language improvements.

Conflicts of Interest: The authors declare no conflict of interest. 


\section{References}

1. IRENA. Global Renewables Outlook: Energy transformation 2050; Edition 2020; International Renewable Energy Agency: Abu Dhabi, UAE, 2020; ISBN 978-92-9260-238-3.

2. NVE. Overview of Norway's Electricity History. Norges Vassdrags- og Energidirektorat; NVE: Oslo, Norway, 2017; ISBN 978-82-410-1567-0.

3. Juárez, A.; Adeva-Bustos, A.; Alfredsen, K.; Dønnum, B.O. Performance of A Two-Dimensional Hydraulic Model for the Evaluation of Stranding Areas and Characterization of Rapid Fluctuations in Hydropeaking Rivers. Water 2019, 11, 201. [CrossRef]

4. Halleraker, J.H.; Saltveit, S.J.; Harby, A.; Arnekleiv, J.V.; Fjeldstad, H.-P.; Kohler, B. Factors influencing stranding of wild juvenile brown trout (Salmo trutta) during rapid and frequent flow decreases in an artificial stream. River Res. Appl. 2003, 19, 589-603. [CrossRef]

5. Hunter, M.A. Hydropower Flow Fluctuations and Salmonids: A Review of the Biological Effects, Mechanical Causes and Options for Mitigation; Technical Report No. 119; Department of Fisheries: Washington, DC, USA, 1992.

6. Hvidsten, N.A. Mortality of pre-smolt Atlantic salmon, Salmo salar L., and brown trout, Salmo trutta L., caused by rapidly fluctuating water levels in the regulated River Nidelva, central Norway. J. Fish Biol. 1985, 27, 711-718. [CrossRef]

7. Saltveit, S.J. Effect of decreased temperature on growth and smoltification of juvenile atlantic salmon (Salmo salar) and brown trout (Salmo trutta) in a norwegian regulated river. Regul. Rivers Res. Manag. 1990, 5, 295-303. [CrossRef]

8. Forseth, T.; Næsje, T.; Jensen, A.J.; Saksgård, L.; Hvidsten, N.A. Ny forbi-tappingsventil i Alta kraftverk: Betydning for laksebestanden. NINA Oppdragsmeld. 1996, 392, 26. (in Norwegian).

9. Saltveit, S.J.; Brabrand, Å.; Brittain, J.E. Rivers need floods: Management lessons learnt from the regulation of the Norwegian salmon river, Suldalslågen. River Res. Appl. 2019, 35, 1181-1191. [CrossRef]

10. Arnekleiv, J.V.; Koksvik, J.I.; Hvidsten, N.A.; Jensen, A.J. Virkninger av Bratsbergreguleringen (Bratsberg kraftverk) på bunndyr og fisk i Nidelva, Trondheim (1982-1986). Vitenskapsmuseet Rapp. Zool. Ser. 1994, 7, 1-56. (In Norwegian)

11. Saltveit, S.J.; Halleraker, J.H.; Arnekleiv, J.V.; Harby, A. Field experiments on stranding in juvenile Atlantic salmon (Salmo salar) and brown trout (Salmo trutta) during rapid flow decreases caused by hydropeaking. Regul. Rivers 2001, 17, 609-622. [CrossRef]

12. Young, P.S.; Cech, J.J.; Thompson, L.C. Hydropower-related pulsed-flow impacts on stream fishes: A brief review, conceptual model, knowledge gaps, and research needs. Rev. Fish Biol. Fish. 2011, 21, 713-731. [CrossRef]

13. Vila-Martínez, N.; Caiola, N.; Ibáñez, C.; Benejam, L.; Brucet, S. Normalized abundance spectra of fish community reflect hydro-peaking on a Mediterranean large river. Ecol. Indic. 2019, 97, 280-289. [CrossRef]

14. Hedger, R.D.; Sauterleute, J.; Sundt-Hansen, L.E.; Forseth, T.; Ugedal, O.; Diserud, O.H.; Bakken, T.H. Modelling the effect of hydropeaking-induced stranding mortality on Atlantic salmon population abundance. Ecohydrology 2018, 11, e1960. [CrossRef]

15. Valentin, S.; Souchon, Y.; Wasson, J.-G. Evaluation of hydropeaking effects on fish community and habitat. In Rehabilitation of Freshwater Fisheriesp; Cowx, I., Ed.; Fishing News Books; Blackwell Scientific Publications Ltd.: Oxford, UK, 1995; pp. 138-151.

16. Valentin, S.; Lauters, F.; Sabaton, C.; Breil, P.; Souchon, Y. Modelling temporal variations of physical habitat for brown trout (Salmo trutta) in hydropeaking conditions. Regul. Rivers 1996, 12, 317-330. [CrossRef]

17. Perry, S.A.; Perry, W.B. Effects of experimental flow regulation on invertebrate drift and stranding in the Flathead and Kootenai Rivers, Montana, USA. Hydrobiologia 1986, 134, 171-182. [CrossRef]

18. Danehy, R.J.; Bilby, R.E.; Owen, S.; Duke, S.D.; Farrand, A. Interactions of baseflow habitat constraints: Macroinvertebrate drift, stream temperature, and physical habitat for anadromous salmon in the Calapooia River, Oregon. Aquat. Conserv. Mar. Freshw. Ecosyst. 2017, 27, 653-662. [CrossRef]

19. James, A.B.W.; Dewson, Z.S.; Death, R.G. The effect of experimental flow reductions on macroinvertebrate drift in natural and streamside channels. River Res. Appl. 2008, 24, 22-35. [CrossRef]

20. Jones, N.E. The dual nature of hydropeaking rivers: Is ecopeaking possible? River Res. Appl. 2013, 30, 521-526. [CrossRef] 
21. Kjaerstad, G.; Arnekleiv, J.V.; Speed, J.D.M.; Herland, A.K. Effects of hydropeaking on benthic invertebrate community composition in two central Norwegian rivers. River Res. Appl. 2018, 34, 218-231. [CrossRef]

22. Bruno, M.C.; Maiolini, B.; Carolli, M.; Silveri, L. Short time-scale impacts of hydropeaking on benthic invertebrates in an Alpine stream (Trentino, Italy). Limnologica 2010, 40, 281-290. [CrossRef]

23. Aas, Ø.; Onstad, O. Strategic and temporal substitution among anglers and white-water kayakers: The case of an urban regulated river. J. Outdoor Recreat. Tour. 2013, 1-2, 1-8. [CrossRef]

24. Zippin, C. The Removal Method of Population Estimation. J. Wildl. Manag. 1958, 22, 82-89. [CrossRef]

25. Bohlin, T.; Hamrin, S.; Heggberget, T.G.; Rasmussen, G.; Saltveit, S.J. Electrofishing-Theory and practice with special emphasis on salmonids. Hydrobiologia 1989, 173, 9-43. [CrossRef]

26. Forseth, T.; Forsgren, E. Electrofishing. Old problems and new challenges. NINA Rep. 2008, 488, 74. (In Norwegian)

27. Sokal, R.R.; Rohlf, F.J. Biometry. In The Principles and Practice of Statistics in Biological Research; W.H. Freeman \& Co.: NewYork, NY, USA, 1995.

28. Harby, A.; Halleraker, J. Ecological impacts of hydropeaking in rivers. Int. J. Hydropower Dams 2001, 8, 132-135.

29. Casas-Mulet, R.; Alfredsen, K.; Brabrand, Å.; Saltveit, S.J. Hydropower operations in groundwater-influenced rivers: Implications for Atlantic salmon, Salmo salar, early life stage development and survival. Fish. Manag. Ecol. 2016, 23, 144-151. [CrossRef]

30. Flodmark, L.; Urke, H.A.; Halleraker, J.H.; Arnekleiv, J.V.; Vøllestad, L.A.; Poleo, A.B.S. Cortisol and glucose responses in juvenile brown trout subjected to a fluctuating flow regime in an artificial stream. J. Fish Biol. 2002, 60, 238-248. [CrossRef]

31. Saltveit, S.J.; Bremnes, T.; Lindås, O.R. Effect of sudden increase in discharge in a large river on newly emerged Atlantic salmon (Salmo salar) and brown trout (Salmo trutta) fry. Ecol. Freshw. Fish 1995, 4, 168-174. [CrossRef]

32. Pulg, U.; Vollset, K.W.; Velle, G.; Stranzl, S. First observations of saturopeaking: Characteristics and implications. Sci. Total. Environ. 2016, 573, 1615-1621. [CrossRef]

33. Casas-Mulet, R.; Alfredsen, K.; Brabrand, Å.; Saltveit, S.J. Survival of eggs of Atlantic salmon (Salmo salar) in a drawdown zone of a regulated river influenced by groundwater. Hydrobiologia 2015, 743, 269-284. [CrossRef]

34. Saltveit, S.J.; Brabrand, Å. Incubation, hatching and survival of eggs of Atlantic salmon (Salmo salar) in spawning redds influenced by groundwater. Limnologica 2013, 43, 325-331. [CrossRef]

35. Heggenes, J.; Krog, O.M.W.; Lindås, O.R.; Dokk, J.G.; Bremnes, T. Homeostatic behavioural (Salmo trutta) become nocturnal during winter. J. Animal Ecol. 1993, 62, 295-308. [CrossRef]

36. Scruton, D.A.; Pennell, C.; Ollerhead, L.M.N.; Alfredsen, K.; Stickler, M.; Harby, A.; Robertson, M.; Clarke, K.D.; LeDrew, L.J. A synopsis of 'hydropeaking' studies on the response of juvenile Atlantic salmon to experimental flow alteration. Hydrobiologia 2008, 609, 263-275. [CrossRef]

37. Sauterleute, J.F.; Charmasson, J. A computational tool for the characterisation of rapid fluctuations in flow and stage in rivers caused by hydropeaking. Environ. Model. Softw. 2014, 55, 266-278. [CrossRef]

38. Bakken, T.H.; Forseth, T.; Harby, A. Environmental Impacts of Hydropeaking. Knowledge Status and Advice to Authorities and the Industry. NINA Them. Rep. 2016, 205. (In Norwegian)

39. Puffer, M.; Berg, O.K.; Huusko, A.; Vehanen, T.; Forseth, T.; Einum, S. Seasonal Effects of Hydropeaking on Growth, Energetics and Movement of Juvenile Atlantic Salmon (Salmo Salar). River Res. Appl. 2015, 31, 1101-1108. [CrossRef]

40. Puffer, M.; Berg, O.K.; Saltveit, S.J.; Forseth, T.; Einum, S. Energetic Consequences of Stranding of Juvenile Atlantic Salmon (Salmo salar L.). J. Water Resour. Prot. 2017, 9, 163-182. [CrossRef]

Publisher's Note: MDPI stays neutral with regard to jurisdictional claims in published maps and institutional affiliations. 